Revista Brasileira de Farmacognosia Brazilian Journal of Pharmacognosy 21(2): 290-295, Mar./Apr. 2011

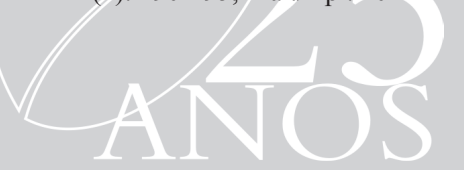

Article

Received 29 Nov 2010

Accepted 8 Mar 2011

Available online 20 May 2011

Keywords:

Antifungal activities

Brazilian seaweeds

Candida

Cryptococcus

infectious diseases

Laurencia

ISSN 0102-695X

doi: $10.1590 / \mathrm{S} 0102-695 \mathrm{X} 2011005000085$

\section{Screening for antifungal activities of extracts of the Brazilian seaweed genus Laurencia (Ceramiales, Rhodophyta)}

\author{
Erika M. Stein, ${ }^{* 1}$ Pio Colepicolo, ${ }^{2}$ Felipe A. K. Afonso, ${ }^{2}$ Mutue \\ T. Fujii
}

\author{
${ }^{1}$ Departamento de Botânica, Instituto de Biociências, Programa de Pós- \\ graduação, Universidade de São Paulo, Brazil, \\ ${ }^{2}$ Departamento de Bioquímica, Instituto de Química, Universidade de São \\ Paulo, Brazil, \\ ${ }^{3}$ Núcleo de Pesquisa em Ficologia, Instituto de Botânica, Brazil.
}

\begin{abstract}
The resistance of pathogens to commonly used antibiotics has enhanced morbidity and mortality and has triggered the search for new drugs. Several species of the red alga genus Laurencia are very interesting candidates as potential sources of natural products with pharmaceutical activity because they are known to produce a wide range of chemically interesting halogenated secondary metabolites. This is an initial report of the antifungal activities of the secondary metabolites of five species of Laurencia, collected in the state of Espírito Santo, against three strains of pathogenic fungi: Candida albicans (CA), Candida parapsilosis (CP), and Cryptococcus neoformans $(\mathrm{CN})$. Minimum inhibitory concentrations (MIC) of the algal extracts were determined by serial dilution method in RPMI 1640 Medium in 96-well plates according to the NCCLS and microbial growth was determined by absorbance at $492 \mathrm{~nm}$. A result showing maintenance or reduction of the inoculum was defined as fungistatic, while fungicidal action was no observed growth in the $10 \mu \mathrm{L}$ fungistatic samples subcultured in Sabouraud Agar. Our results indicate that apolar extracts of Laurencia species possess antifungal properties and encourage continued research to find new drugs for therapy of infectious diseases in these algae.
\end{abstract}

\section{Introduction}

Currently, multiple drug resistance of human pathogenic microorganisms is due to the indiscriminate use of the commercial antimicrobials commonly used for the treatment of infectious diseases (Karaman et al., 2003). The search for new, more specific and better adapted antimicrobial agents has been further stimulated by the occurrence of fatal opportunistic infections associated with AIDS, antineoplasic chemotherapy and transplants (Penna et al., 2001).

As a consequence of the increasing demand for biodiversity in screening programs for potential therapeutic activities of natural products, there is an increased interest in marine fauna and flora throughout the world (Sasidharan et al., 2010). In this context, tropical marine algae have proven to be a rich source of bioactive compounds of potential biomedicinal interest (Sieburth, 1964; Burkholder, 1973; Caccamese et al., 1981; Reichelt \& Borowitzka, 1984; Robles-Centeno et al., 1996; Plaza et al., 2010).
Brazil occupies a prominent position as an interesting source of natural products due to the richness of its biodiversity, including the red seaweed genus Laurencia (Fujii \& Sentíes, 2005), which is known to produce numerous biologically active halogenated secondary metabolites with a diversity of structural features (Erickson, 1983), predominantly sesquiterpenes, diterpenes, and acetylenes (Blunt et al., 2005). Many of these metabolites have been isolated and their structures determined, but their biological activity needs to be investigated in more detail (Ireland et al., 2000).

There are numerous studies testing inhibition against bacteria, some viruses and marine fungi, but there are few studies of the activity of compounds or extracts of Laurencia against human pathogenic fungi. Ballantine et al. (1987) collected Laurencia obtusa (Huds.) J.V. Lamour., Yuzurua poiteaui (J.V. Lamour.) Martin-Lescanne (as Laurencia poitei) and Laurencia sp. from Puerto Rico and evaluated the antifungal properties of chloroform/ methanol (2:1) extracts against Candida albicans. The 
L. obtusa extract showed a $0.5 \mathrm{~mm}$ inhibition using the disc-agar method.

Most authors use agar diffusion assays to determine the antimicrobial activity of algal extracts. The technique works adequately with well-defined inhibitors (Hewitt \& Vincent, 1989), but with extracts that contain unknown components there are problems with false positive and false negative results (Eloff, 1998). The type of agar, the salt concentration, the incubation temperature, and the molecular size of the antimicrobial components can all influence the results obtained with agar diffusion assays (Marsh \& Goode, 1994). Furthermore, this technique also cannot distinguish between fungicidal (the lowest concentration of the agent that results in no growth) and fungistatic (the lowest concentration of the agent that results in the maintenance or reduction of the inoculum) effects (Hammer et al., 2003) and does not permit determination of the minimum inhibitory concentration (MIC) (Eloff, 1998).

The present study is an initial report of the results of screening assays for a variety of biological activities with extracts of Laurencia species, with the aim of identifying novel and interesting potentially useful therapeutic activities. In this paper, we describe the antifungal activities of extracts of five Laurencia species collected in the state of Espírito Santo, Southeastern Brazil, measured by using a sensitive and rapid serial dilution technique in 96-well microplates.

\section{Materials and Methods}

\section{Algae and preparation of the extracts}

The red seaweeds Laurencia aldingensis Saito \& Womersley (LA), Laurencia catarinensis Cord.-Mar. \& M.T. Fujii (LC), Laurencia dendroidea J. Agardh (LD), Laurencia intricata J.V. Lamour. (LI) and Laurencia translucida M.T. Fujii \& Cord.Mar. (LT) were collected in two counties of Espírito Santo State, Southeastern Brazil (Table 1). Vouchers of representative specimens were deposited in the Maria Eneyda P. Kauffmann Fidalgo Herbarium (SP) at the Instituto de Botânica in São Paulo.

After collection, the fresh algae were washed thoroughly with seawater, followed by fresh water to remove sand particles and epiphytes. The cleaned material was stored frozen at $-20{ }^{\circ} \mathrm{C}$ until preparation of the extracts. For that purpose, approximately 30 $\mathrm{g}$ of dried and powdered alga was added to $300 \mathrm{~mL}$ of hexane and allowed to soak overnight. To ensure complete extraction, this procedure was repeated on three subsequent days. The extract was filtered and concentrated on a rotary evaporator. The same procedure was repeated using chloroform, methanol and water, generating the hexane, chloroform, methanol and aqueous extracts. In addition, a crude water extract was prepared from $30 \mathrm{~g}$ of fresh alga in water to obtain a clean, non-toxic extract preparation that was then concentrated on a Speed Vac. The dried extracts were re-dissolved in $10 \%$ ethanol (by volume) or water to yield a solution containing $4 \mathrm{mg}$ of extract per $\mathrm{mL}$ of growth medium.

\section{Microorganisms}

The test organisms included three American Type Culture Collection (ATCC) fungal strains: Candida albicans ATCC 10231 (CA), Candida parapsilosis ATCC 29212 (CP) and Cryptococcus neoformans ATCC 90112 $(\mathrm{CN})$.

\section{Antifungal Drug and microdilution tray}

Fluconazole was obtained as a reagent-grade powder from Sigma. Microdilution trays containing serial dilutions of the antifungal agent in RPMI 1640 medium (Sigma) were prepared in a single lot and stored frozen at $-20{ }^{\circ} \mathrm{C}$ until used in the study.

\section{Broth microdilution assay}

Broth microdilution assays were performed according to National Committee for Clinical Laboratory Standards (NCCLS) for the establishment of quality control and referenced strain, using the methods (NCCLS, 2002) with minor modifications.

Yeast inocula were prepared by growing isolates on Sabouraud dextrose agar (SDA) for 24-48 h at $35^{\circ} \mathrm{C}$ and then suspending growth in $5 \mathrm{~mL}$ of saline $\left(0.145\right.$ mol. $\left.\mathrm{L}^{-1}\right)$ prepared in sterile distilled water. The optical density of this suspension was adjusted to 0.5 McFarland standard turbidity in a Shimadzu UV1650 PC spectrophotometer (Kyoto, Japan) to obtain a concentration of $1 \times 10^{6}$ to $5 \times 10^{6}$ UFC.mL $\mathrm{m}^{-1}$ and then diluted 1:100 followed by 1:20 in RPMI 1640 medium to obtain a final inoculum concentration of $5.0 \times 10^{2}$ to $2.5 \times 10^{3}$ UFC. $\mathrm{mL}^{-1}$. Serial dilutions were prepared in 96-well microplates with $50 \mu \mathrm{L}$ of RPMI 1640 Medium in each well as described (Zgoda \& Porter, 2001) with the following modifications. A $50 \mu \mathrm{L}$ aliquot of initially prepared extract at the concentration of $4 \mathrm{mg} / \mathrm{ml}$ was added into the first well. Then, $50 \mu \mathrm{L}$ aliquots of the corresponding serial dilutions were transferred into six consecutive wells to obtain final concentrations ranging from 1,000 to $31.25 \mu \mathrm{g} \cdot \mathrm{mL}^{-1}(50 \mu \mathrm{L})$. The last well contained just $50 \mu \mathrm{L}$ of nutrient broth plus an aliquot of the extract vehicle ( $10 \%$ ethanol or water), used as the negative control. After serial dilution, $50 \mu \mathrm{L}$ of the inoculum were added to the wells. The final volume 
in each well was $100 \mu \mathrm{L}$. Fluconazole was prepared in water at concentrations ranging from 64 to $2 \mu \mathrm{g} . \mathrm{m}^{\mathrm{L}-1}$ and used as the standard for the positive control.

Spectrophotometric determination of the Minimum Inhibitory Concentration (MIC)

For yeasts, the MIC value was determined as the lowest concentration of the extract in the broth medium that resulted in maintenance or reduction of the inoculum (Hammer et al., 2003). Spectrophotometric readings on each well were performed with a Tecan M200 automated plate reader (Männedorf, Switzerland) set at $492 \mathrm{~nm}$ after the well had been agitated. MIC endpoints were determined as the first concentration of the antifungal agent at which turbidity in the well was $\geq 50 \%$ less than that in the control well (Pfaller et al. 1995).

\section{Determination of Concentration Effects (CE)}

The concentration effects were determined by subculturing $10 \mu \mathrm{L}$ from each well of the microtiter tray that showed inhibition, carried out by spot inoculating onto SDA and incubating aerobically at 35 ${ }^{\circ} \mathrm{C}$. Any inoculum growth on agar plates corresponds to a fungistatic effect, while a fungicidal effect is characterized by no observed growth of the $10 \mu \mathrm{L}$ fungistatic samples subcultured in Sabouraud Agar (Hammer et al, 2003).

\section{Statistical analysis}

The extract fractions were prepared in triplicate and measured for their antifungal activity, expressed as the percentage of activity (\%AE) with the formula adapted from Felício et al. (2008):

$$
\% A E=100-\frac{\mathrm{AE}-\mathrm{AEB}}{\mathrm{AC}-\mathrm{ACB}} \times 100
$$

Where AE represents the "absorbance of the test plates after the incubation time"; AEB is the "absorbance of plates containing medium, sample and inoculum at $\mathrm{t}=0$ of incubation"; $\mathrm{AC}$ is the "absorbance of plates containing negative control (with or without vehicle) (100\% of inoculum growth)"; and ACB is the "absorbance of plates containing culture medium". All of the MIC values were calculated by nonlinear regression.

\section{Results and discussion}

The data obtained by the microdilution technique are collected in Table 2. The MIC of the chloroform and methanol extracts of L. dendroidea were $<31.25 \mu \mathrm{g} . \mathrm{mL}^{-1}$ against CA with a fungistatic effect; the chloroform extract of $L$. catarinensis showed the same results against $\mathrm{CP}$. A fungistatic effect was observed for the methanol extract of $L$. aldingensis against $\mathrm{CP}$ $\left(\mathrm{MIC}<31.25 \mu \mathrm{g} \cdot \mathrm{mL}^{-1}\right), \mathrm{CN}\left(33.9 \mu \mathrm{g} . \mathrm{mL}^{-1}\right)$ and $\mathrm{CA}$ $\left(65.2 \mu \mathrm{g} . \mathrm{mL}^{-1}\right)$. The fungicidal effects of the hexane and chloroform extracts of $L$. aldingensis against $\mathrm{CP}$ were indicated by MIC values of 49.0 and $57.8 \mu \mathrm{g} . \mathrm{mL}^{-1}$, respectively; the same extracts were fungistatic agaist $\mathrm{CA}$ and $\mathrm{CN}$ between the concentrations of 85.3 and $130.8 \mu \mathrm{g} . \mathrm{mL}^{-1}$. Moreover, the chlroform extract of L. catarinensis was fungicidal agaist $\mathrm{CA}$ and $\mathrm{CN}$ at 303.8 and $600.4 \mu \mathrm{g} . \mathrm{mL}^{-1}$, respectively. Of all of the extracts of $L$. intricata, the chloroform extract was the most active, with a MIC higher than $220 \mu \mathrm{g} \cdot \mathrm{mL}^{-1}$. The Laurencia translucida extracts showed no activity against CA, while between 177 and $743 \mu \mathrm{g} \cdot \mathrm{mL}^{-1}$ were required to observe a fungistatic effect against $\mathrm{CP}$ or $\mathrm{CN}$. Comparison of the three different fungal strains indicates that $C$. albicans was the most susceptible to maintenance or reduction of growth by the extracts, while $C$. parapsilosis was the most susceptible to the fungicidal effects of the algal extracts. L. aldingensis appears to be a particularly interesting alga, showing activity against all three fungal strains tested.

In general, the results show that the aqueous extracts stimulate cells growth, except for the crude water extracts of $L$. aldingensis and L. dendroidea, which show a reasonable percentage of inhibition (110 $\mu \mathrm{g} . \mathrm{mL}^{-1}$ and $100 \mu \mathrm{g} \cdot \mathrm{mL}^{-1}$, respectively) agaist $\mathrm{CN}$.

The MIC values of the positive control fluconazole were in agreement with those reported by NCCLS (MIC $\left.\leq 2 \mu \mathrm{g} . \mathrm{mL}^{-1}\right)$ for the reference antifungal agent.

Of the known algal secondary metabolites with biological activities, approximately $90 \%$ are lipidsoluble (Norris \& Fenical, 1985). The survey reported here was undertaken to assess the occurrence of lipidsoluble bioactive materials in these macroalgal species and to evaluate them more thoroughly as sources of potentially useful bioactive substances.

The present technique using 96-well microplates and spectrophotometric detection of the MIC was successfully applied to compare the antifungal activities of extracts from different species of Laurencia. The method is robust, inexpensive, relatively quick and 30-fold more sensitive than other methods commonly used in the literature; in addition, it requires only a small quantity of sample, can be applied to a large number of samples (very useful for screening), and provides a permanent record of the results (Ellof, 1998).

The importance of investigating the activity of crude extracts lies in identifying promising candidates for additional investigation. In addition, the activity of 
an extract may be due synergy between two or more components and other beneficial pharmacological or medicinal properties can be explored. For extracts that show activity, subsequent fractionation or isolation of the individual components is necessary to obtain an understanding of the activity of each individual component and of the contribution of each component to the overall activity of the extract as a whole. In conclusion, this study suggests that apolar extracts of several species of Laurencia possess interesting antifungal properties, which should encorage the continued search for new drugs for therapy of infectious diseases derived from marine algae.

\section{Acknowledgment}

This work was supported by the Brazilian research funding agencies Fundação de Amparo a Pesquisa do Estado de São Paulo, Conselho Nacional de Desenvolvimento Científico e Tecnológico and
Coordenação de Aperfeiçoamento de Pessoal de Nível Superior, Ministério da Saúde, Ministério de Ciência e Tecnologia and CNPq-INCT-Redoxoma.

Table 1. List of the species used in the experiments, with collection information and voucher number.

\begin{tabular}{|c|c|c|}
\hline Species & Collection data & Voucher \\
\hline $\begin{array}{l}\text { Laurencia aldingensis } \\
\text { Saito \& Womersley } \\
\text { (LA) }\end{array}$ & $\begin{array}{l}\text { Espírito Santo State, Anchieta, } \\
\text { Praia dos Castelhanos, col. } \\
\text { E.M. Stein, 01 Jul. } 2007\end{array}$ & SP 399.933 \\
\hline $\begin{array}{l}\text { Laurencia catarinensis } \\
\text { Cord.-Mar. \& M.T. } \\
\text { Fujii (LC) }\end{array}$ & $\begin{array}{l}\text { Espírito Santo State, Anchieta, } \\
\text { Praia dos Castelhanos, col. } \\
\text { E.M. Stein, } 01 \text { Jul. } 2007\end{array}$ & SP 400.209 \\
\hline $\begin{array}{l}\text { Laurencia dendroidea } \\
\text { J. Agardh (LD) }\end{array}$ & $\begin{array}{l}\text { Espírito Santo State, } \\
\text { Anchieta, Praia de Parati, col. } \\
\text { E.M. Stein, } 30 \text { Jun. } 2007\end{array}$ & SP 400.198 \\
\hline $\begin{array}{l}\text { Laurencia intricata } \\
\text { J.V.Lamour. (LI) }\end{array}$ & $\begin{array}{l}\text { Espírito Santo State, } \\
\text { Guarapari, Praia de Meaípe, } \\
\text { col. E.M. Stein, } 09 \text { Apr. } 2009\end{array}$ & SP 400.207 \\
\hline $\begin{array}{l}\text { Laurencia translucida } \\
\text { M.T. Fujii \& Cord.- } \\
\text { Mar. (LT) }\end{array}$ & $\begin{array}{l}\text { Espírito Santo State, Anchieta, } \\
\text { Praia dos Castelhanos, col. } \\
\text { E.M. Stein, } 09 \text { Apr. } 2009\end{array}$ & SP 400.830 \\
\hline
\end{tabular}

Table 2. Spectrophotometric Minimal Inhibitory Concentration endpoints ( $\leq 50 \%$ less than that in the control well), expressed in $\mu \mathrm{g} / \mathrm{mL}$, of Laurencia aldingensis, L. catarinensis, L. intricata, L. dendroidea, L. translucida extracts against the reference strains Candida albicans, Candida parapsilosis, Cryptococcus neoformans. End points were measured at $492 \mathrm{~nm}$.

\begin{tabular}{|c|c|c|c|c|}
\hline Extract & & $\begin{array}{c}\text { C. albicans } \\
\text { (ATCC 10231) }\end{array}$ & $\begin{array}{l}\text { C. parapsilosis } \\
\text { (ATCC 29212) }\end{array}$ & $\begin{array}{l}\text { C. neoformans } \\
\text { (ATCC 90112) }\end{array}$ \\
\hline \multirow{2}{*}{ LA-HE } & MIC & 100.6 & 49.0 & 130.8 \\
\hline & Concentration effect & Fungistatic & Fungicidal & Fungistatic \\
\hline \multirow{2}{*}{ LA-CE } & MIC & 85.3 & 57.8 & 100.2 \\
\hline & Concentration effect & Fungistatic & Fungicidal & Fungistatic \\
\hline \multirow{2}{*}{ LA-ME } & MIC & 65.2 & $<31.25$ & 33.9 \\
\hline & Concentration effect & Fungistatic & Fungistatic & Fungistatic \\
\hline \multirow{2}{*}{ LA-AE } & MIC & n.d & n.d. & n.d. \\
\hline & Concentration effect & - & - & - \\
\hline \multirow[t]{2}{*}{ LA-CW } & MIC & n.d & n.d. & 110.0 \\
\hline & Concentration effect & - & - & Fungistatic \\
\hline \multirow{2}{*}{ LC-HE } & MIC & n.d. & 403.4 & n.d. \\
\hline & Concentration effect & - & Fungistatic & - \\
\hline \multirow{2}{*}{ LC-CE } & MIC & 303.8 & $<31.25$ & 600.4 \\
\hline & Concentration effect & Fungicidal & Fungistatic & Fungicidal \\
\hline \multirow{2}{*}{ LC-ME } & MIC & n.d & n.d. & n.d. \\
\hline & Concentration effect & - & - & - \\
\hline \multirow{2}{*}{ LC-AE } & MIC & n.d & n.d. & n.d. \\
\hline & Concentration effect & - & - & - \\
\hline \multirow{2}{*}{ LD-HE } & MIC & 183.6 & 812.50 & 542.1 \\
\hline & Concentration effect & Fungistatic & Fungistatic & Fungistatic \\
\hline \multirow{2}{*}{ LD-CE } & MIC & $<31.25$ & 176.6 & 176.0 \\
\hline & Concentration effect & Fungistatic & Fungistatic & Fungistatic \\
\hline \multirow{2}{*}{ LD-ME } & MIC & $<31.25$ & n.d. & 159.0 \\
\hline & Concentration effect & Fungistatic & - & Fungistatic \\
\hline
\end{tabular}




\begin{tabular}{|c|c|c|c|c|}
\hline \multirow{2}{*}{ LD-AE } & MIC & n.d & n.d. & n.d. \\
\hline & Concentration effect & - & - & - \\
\hline \multirow{2}{*}{ LD-CW } & MIC & n.d & n.d. & 100.0 \\
\hline & Concentration effect & - & - & Fungistatic \\
\hline \multirow[t]{2}{*}{ LI-HE } & MIC & n.d & n.d. & n.d. \\
\hline & Concentration effect & - & - & - \\
\hline \multirow[t]{2}{*}{ LI-CE } & MIC & 258.0 & 222.7 & 268.6 \\
\hline & Concentration effect & Fungistatic & Fungistatic & Fungistatic \\
\hline \multirow[t]{2}{*}{ LI-ME } & MIC & n.d & n.d. & n.d. \\
\hline & Concentration effect & - & - & - \\
\hline \multirow{2}{*}{ LI-AE } & MIC & n.d & n.d. & n.d. \\
\hline & Concentration effect & - & - & - \\
\hline \multirow{2}{*}{ LI-CW } & MIC & 367.6 & 725.4 & 444.4 \\
\hline & Concentration effect & Fungistatic & Fungistatic & Fungistatic \\
\hline \multirow{2}{*}{ LT-HE } & MIC & n.d & 177.8 & 648.2 \\
\hline & Concentration effect & - & Fungistatic & Fungistatic \\
\hline \multirow{2}{*}{ LT-CE } & MIC & n.d & 302.0 & n.d. \\
\hline & Concentration effect & - & Fungistatic & - \\
\hline \multirow{2}{*}{ LT-ME } & MIC & n.d & 193.7 & n.d. \\
\hline & Concentration effect & - & Fungistatic & - \\
\hline \multirow{2}{*}{ LT-AE } & MIC & n.d & 189.2 & 274.7 \\
\hline & Concentration effect & - & Fungistatic & Fungistatic \\
\hline \multirow{2}{*}{ LT-CW } & MIC & n.d & n.d. & 743.7 \\
\hline & Concentration effect & - & - & Fungistatic \\
\hline \multirow{2}{*}{ Fluconazole } & MIC & $<2$ & $<2$ & 2.4 \\
\hline & Concentration effect & Fungicidal & Fungicidal & Fungicidal \\
\hline
\end{tabular}

n.d: not determined; MIC: minimal inhibitory concentration $(\mu \mathrm{g} / \mathrm{mL})$.

\section{References}

Ballantine DL, Gerwick WH, Velez SM, Alexander E, Guevara P 1987. Antibiotic activity of lipid-soluble extracts from Caribbean marine algae. Hydrobiologia 151/152: 463-469.

Blunt JW, Copp BR, Munro MHG, Northcote PT, Prinsep MR 2005. Marine natural products. Nat Prod Rep 22: 1561.

Burkholder PR 1973. The ecology of marine antibiotics and coral reefs. In Jones OA, Endean R (eds.) Biology and Geology of Coral Reefs, vol 2, biol 1. New York: Academic Press, p 117-182.

Caccamese S, Azzolina R, Furnari G, Cormaci M, Grasso S 1981. Antimicrobial and antiviral activities of some marine algae from eastern Sicily. Bot Mar 24: 365 367.

Ellof JN 1998. Which extractant should be used for the screening and isolation of antimicrobial components from plants? J Ethnopharmacol 60: 1-6.

Erickson KL 1983. Constituints of Laurencia. vol 5. In PJ Scheur (ed.) Marine Natural Products. New York: Academic Press, p 131-257.
Felício R, Albuquerque S, Young MCM, Yokoya NS, Debonsi H M 2008. Trypanocidal, leishmanicidal and antifungal potential from marine red alga Bostrychia tenella J. Agardh (Rhodomelaceae, Ceramiales). J Pharm Biom Anal 52: 763-769.

Fujii MT, Sentíes A 2005. Taxonomia do complexo Laurencia (Rhodomelaceae, Rhodophyta) do Brasil, com ênfase nas espécies dos estados de São Paulo e do Espírito Santo. In Sentíes A, Dreckmann KM (eds.) Monografias Ficológicas II. Iztapalapa: Universidad Autônoma Metropolitana, p. 69-135.

Hammer KA, Carson CF, Riley TV 2003. Antifungal activity of the components of Melaleuca alternifolia (tea tree) oil. J Appl Microbiol 95: 853-860.

Hewitt W, Vincent S 1989. Theory and application of microbiologycal assay. London: Academic Press.

Karaman I, Sahin F, Güllüce M, Ögütçü H, Sengül M, Adigüzel A 2003. Antimicrobial activity of aqueous and methanol extracts of Juniperus oxycedrus L. $J$ Ethnopharmacol 85: 231-235.

Marsh J, Goode J A 1994. Antimicroabial peptides. Ciba Foundation Symposium. Chichester, Inglaterra.

Ireland CM, Copp BR, Foster MP, McDonald LA, Radisky 
DC, Swersey JC 2000. Bioactive compounds from the sea. In: Martin RE, Carter EP, Davis LM, Flick, Jr GJ (eds). Marine and Freshwater Products Handbook. Lancaster: Martin Technomic Publishing, p.641-661.

National Committee Clinical Laboratory Standards (NCCLS) 2002. Reference method for broth dilution antifungal susceptibility testing of yeasts. Approved Standard. NCCLS document M27-A2, Wayne, PA.

Norris JN, Fenical WH 1985. Natural products chemistry: uses in ecology and systematics. In Littler MM, Littler DS (eds.) Handbook of Phycological Methods. Ecological Field Methods: Macroalgae. New York: Cambridge Univ. Press, p.121-145.

Penna C, Marino S, Vivot E, Cruan MC, Muñoz JD, Cruañes J, Ferraro G, Gutkind G, Martino V 2001. Antimicrobial activity of Argentine plants used in the treatment of infectious diseases. Isolation of active compounds from Sebastiania brasiliensis. J Ethnopharmacol 77: $37-40$

Pfaller MA, Messer SA, Coffmann S 1995. Comparison of visual and spectrophotometric methods of mic endpoint determinations by using broth microdilution methods to test five antifungal agents, including the new triazole D0870. J Clin Microbiol 33: 1094-1097

Plaza M, Santoyo S, Jaime L, Reina GG, Herrero M, Señorás FJ, Ibálnez E 2010. Screening for bioactive compounds from alga. J Pharm Biomed Anal 51: 450-455.
Reichelt JL, Borowitzka MA 1984. Antimicrobial activity from marine algae: Results of a large-scale screening programme. Hydrobiologia 116/117: 158-168

Robles-Centeno PO, Ballantine DL, Gerwick WH 1996. Dynamics of antibacterial activity in three species of Caribbean marine algae as a function of habitat and life history. Hydrobiologia, 326: 457-462.

Sasidharan S, Darah I, Noordin MKMJ 2010. In vitro antimicrobial activity against Pseudomonas aeruginosa and acute oral toxicity of marine algae Gracilaria changii. New biotechnol 27: 390-396.

Sieburth JM 1964. Antibacterial substances produced by marine algae. Developments Industr Microbiol 5:124134.

Zgoda, JR, Porter, JR 2001. A convenient microdilution method for screening natural products against bacteria and fungi. Pharm Biol 39: 221-225.

\section{*Correspondence}

Erika M. Stein

Departamento de Botânica, Instituto de Biociências, Programa de Pós-graduação, Universidade de São Paulo Rua do Matão, 277, 05422-970 São Paulo-SP, Brazil

erikamstein@usp.br

Tel. +55 $113091-3810$ r:248

Fax: $+55113091-2170$ 